Praca oryginalna/Original research article

\title{
Ekspresja CD10 na minimalnych komórkach resztkowych u dzieci z ostrą białaczką limfoblastyczną B-komórkową
}

\author{
Expression of CD10 on minimal residual cells in children with \\ B-cell precursor acute leukemia
}

\author{
Joanna Włodek*, Karolina Bukowska-Strakova, Anna Pituch-Noworolska, \\ Walentyna Balwierz, Marta Surman \\ Katedra Immunologii Klinicznej i Transplantologii UJ CM Klinika Onkologii i Hematologii Dzięcięcej, Kraków, Polska
}

IN F ORMACJE O ARTYKULE

Historia artykułu:

Otrzymano: 10.10 .2016

Zaakceptowano: 14.04 .2017

Dostępne online: 27.05 .2017

\section{Słowa kluczowe:}

- minimalna choroba resztkowa

- ostra białaczka limfoblastyczna

- cytometrii przepływowa

- terapia prednizonem

- ekspresja CD10

Keywords:

- Minimal residual disease

- Acute lymphoblastic leukemia

- Flow cytometry

- Prednisone therapy

- CD10 expression

\begin{abstract}
A B S T R A C T
Background: The most common childhood malignancy is B-cell precursor acute leukemia (BCP-ALL). Leukemic cells remaining in the patient's bone marrow during treatment are the major cause of relapse; therefore, minimal residual disease monitoring (MRD) during the induction therapy is predicting factor of treatment outcome. Multicolor flow cytometry (MFC) is the commonly used technique during follow-up of leukemia in bone marrow. Materials and methods: MRD was assessed by MFC in 44 patients with BCP-ALL from the Oncology and Hematology Department, Children's University Hospitalin Krakow diagnosed between 2011 and 2013. The level of residual leukemic cells and the quality of antigen expression was assessed on leukemic cell on diagnosis day and 15th day of induction chemotherapy. Six-color panel of monoclonal antibodies was used. To achieve expected sensitivity of the method (10-4), at least 300.000 nucleated cells were collected. Results: CD10 expression was changed in residual leukemic cells of most patients on day 15 of treatment, in comparison to day 0 . The most significant decrease of CD10 expression occurs in standard risk group. CD10 level is correlated with the level of blasts in day 15 , which is the most significant in high-risk group. The patients, in whom the level of CD10 expression increases during treatment, were statistically significantly associated with worse response to therapy. Conclusions: The immunophenotypic shifts at day 15 were observed in most patients. Not only are the quantitative MRD results important, but also qualitative changes of immunophenotype of residual leukemic cells might bring additional clinical information.
\end{abstract}

(C) 2017 Polskie Towarzystwo Hematologów i Transfuzjologów, Instytut Hematologii i Transfuzjologii. Published by Elsevier Sp. z o.o. All rights reserved.

\footnotetext{
* Adres do korespondencji: Instytut pediatrii Katedra Immunologii Klinicznej i Transplantologii UJ CM Klinika Onkologii i Hematologii Dzięcięcej, ul. Wielicka 265, 30-663 Kraków, Polska. Tel.: +48 12 658-20-11.

Adres email: joanna.wlodek@doctoral.uj.edu.pl (J. Włodek).

http://dx.doi.org/10.1016/j.achaem.2017.04.002

0001-5814/@ 2017 Polskie Towarzystwo Hematologów i Transfuzjologów, Instytut Hematologii i Transfuzjologii. Published by Elsevier Sp. $\mathrm{z}$ o.o. All rights reserved.
} 


\section{Wprowadzenie}

Ostra białaczka limfoblastyczna (ALL; acute lymphoblastic leukemia) jest najczęstszym nowotworem wieku dziecięcego (ok. 85\% wszystkich nowotworów u dzieci). Najwyższą zachorowalność na ALL obserwuje się w przedziale wiekowym od 2 do 5 lat. W przebiegu tej choroby obserwuje się zaburzoną proliferację oraz akumulację limfoblastów, które lokalizują się w szpiku kostnym, krwi obwodowej oraz węzłach chłonnych. Najczęstszy podtyp ostrej białaczki limfoblastycznej stanowi białaczka z prekursorowych komórek B (BCP-ALL; B-cell prekursor acute leukemia), która charakteryzuje się proliferacją limfoblastów zatrzymanych na wczesnym etapie dojrzewania. Najpowszechniejszą przyczyną niepowodzenia terapii przeciwnowotworowej $u$ pacjentów pediatrycznych z ALL jest wystąpienie wznowy. Pojawia się ona u około 15-20\% pacjentów, co wynosi około 0,7 na 100000 dzieci w Europie. Przy użyciu kombinacji intensywnej chemioterapii, radioterapii czy allogenicznego przeszczepu szpiku kostnego możliwe jest wyleczenie ponad $80 \%$ pacjentów, jednakże w niektórych przypadkach komórki białaczkowe pozostają w szpiku kostnym pacjentów pomimo zastosowanego leczenia, powodując wystąpienie wznowy. $Z$ tego powodu bardzo istotną rolę odgrywa prawidłowa i rzetelna diagnostyka na początkowym etapie leczenia, a także monitorowanie minimalnej choroby resztkowej [1-6].

Minimalna choroba resztkowa (MRD; minimal residua disease) określa ilość komórek białaczkowych, które przetrwały proces leczenia chemioterapeutycznego u pacjentów w fazie remisji, a ich wykrycie możliwe jest jedynie przy użyciu zaawansowanych technik laboratoryjnych, takich jak cytometria przepływowa czy reakcja łańcuchowa polimerazy. MRD jest główną przyczyną występowania wznowy, a ryzyko jej wystąpienia jest szacowane właśnie na podstawie poziomu minimalnej choroby resztkowej. Ocena MRD stanowi także jeden z czynników, na podstawie których dokonuje się klasyfikacji pacjentów do poszczególnych grup ryzyka: standardowego, pośredniego lub wysokiego. Grupa ryzyka jest kliniczną oceną zawansowania choroby [7-10].

Współczesne metody diagnostyki laboratoryjnej w zakresie ostrych białaczek dotyczą oceny cytologicznej komórek krwi obwodowej i szpiku kostnego, zaburzeń genetycznych, enzymów i związków chemicznych w komórkach blastycznych, a także określenia immunofenotypu komórek białaczkowych z wykorzystaniem cytometrii przepływowej. Obecnie cytometria przepływowa jest rutynowo wykorzystywana w diagnostyce chorób hematologicznych. Służy między innymi do różnicowania stadiów dojrzewania komórek, monitorowania postępów leczenia oraz stwierdzenia remisji choroby, a także oceny i kontroli minimalnej choroby resztkowej. Klasyfikacja immunologiczna ostrych białaczek na podstawie immunofenotypu jest możliwa dzięki określonym determinantom antygenowym, które są charakterystyczne dla poszczególnych etapów dojrzewania komórek danej linii. Analiza immunofenotypu komórek prawidłowo różnicujących się oraz komórek białaczkowych pozwala na określenie na jakim etapie różnicowania i dojrzewania zatrzymały się niekontrolowanie proliferujące komórki.
Ekspresja poszczególnych antygenów powierzchniowych i cytoplazmatycznych może się zmieniać w trakcie leczenia [11-14].

Glikokortykosteroidy stosowane są jako jedne z pierwszy leków w czasie terapii u pacjentów $\mathrm{z}$ ostrą białaczką limfoblastyczną, stanowiąc jej istotny element. Wykorzystywane jest ich działanie limfocytolityczne oraz hamowanie procesów podziałowych w limfocytach. Zostało udowodnione, że zmiana poziomu ekspresji poszczególnych antygenów może występować nawet w początkowym etapie leczenia u pacjentów z ostrą białaczką limfoblastyczną wywodzącą się $\mathrm{z}$ komórek $\mathrm{B}$. Zmiany $\mathrm{w}$ immunofenotypie komórek $\mathrm{w}$ trakcie chemioterapii u pacjentów z białaczką B- komórkową mogą również odzwierciedlać wrażliwość na zastosowane leczenie [15-18].

CD10 jest antygenem charakterystycznym dla niedojrzałych limfocytów B, równocześnie stanowiąc marker ostrej białaczki limfoblastycznej typu „common” [19]. Badania prowadzone w ostatnich latach [18] wykazały wpływ leczenia prednizonem na modulację ekspresji CD10. Co ciekawe, stopień modulacji immunofenotypu in vitro koreluje z kliniczną odpowiedzią na prednizon (ocenioną na podstawie badania morfologicznego krwii obwodowej w dniu 8 chemioterapii). Wykazano, że modulacja CD10, a dokładnie spadek poziomu ekspresji tego antygenu, jest znacząco niższy w grupie pacjentów ze złą odpowiedzią na leczenie prednizonem (PPR; prednisone poor response, >1000 komórek białaczkowych we krwi obwodowej po 8 dniach leczenia) w porównaniu $\mathrm{z}$ grupą pacjentów prezentujących dobrą odpowiedz na leczenie prednizonem (PGR; prednisone good response, $<1000$ komórek białaczkowych we krwi obwodowej po 8 dniach leczenia).

\section{Materiały i metody}

Grupę badaną stanowiło 44 pacjentów oddziału Onkologii i Hematologii Uniwersyteckiego Szpitala Dziecięcego w Krakowie, u których w latach 2011-2013 zdiagnozowano ostrą białaczkę limfoblastyczną pochodzącą z komórek B i w czasie leczenia stosowany był prednizon przez okres 8 dni. U pacjentów monitorowano minimalną chorobę resztkową (MRD>0,01\% w dniu 15 leczenia) z wykorzystaniem cytometru przepływowego. Poziom resztkowych komórek białaczkowych, a także ekspresja antygenów, wyrażona jako średnia intensywność fluorescencji (MFI; mean fluorescence intensity) była oceniana na komórkach białaczkowych $\mathrm{w}$ dniu diagnozy oraz $\mathrm{w}$ dniu 15. zastosowanego leczenia chemioterapeutycznego. W trakcie analizy wykorzystywany był sześciokolorowy panel przeciwciał monoklonalnych. Aby uzyskać oczekiwaną wrażliwość metody (10-4), analizowano zbiór składający się z 300000 komórek jądrzastych.

\section{Wyniki}

Szpik kostny pobierany był od pacjentów w dniu diagnozy (dzień 0) oraz w 15. dniu leczenia. Nie zaobserwowano różnić w poziomie ekspresji CD10 (wyrażonym jako MFI) 


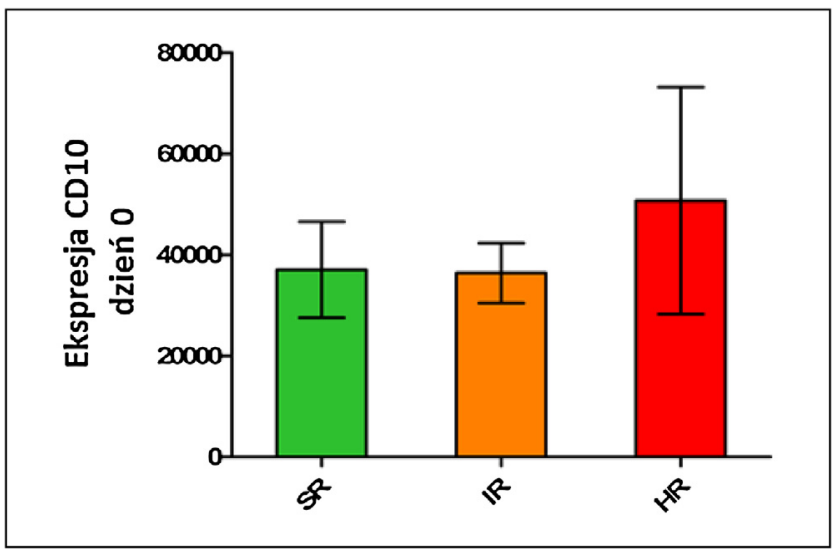

Ryc. 1 - Poziom ekspresji CD10 w dniu zerowym w zależności od grupy ryzyka: standardowego (SR), pośredniego (IR) i wysokiego (HR)

Fig. 1 - The level of CD10 expression at day 0 in standard risk (SR), intermediate (IR) risk, and high-risk (HR) groups

pomiędzy grupą standardowego, pośredniego i wysokiego ryzyka w dniu zerowym (początek leczenia) (Ryc. 1). Zaobserwowano różnicę w poziomie ekspresji CD10 w dniu 15 w zależności od grupy ryzyka (Ryc. 2). Zmiana poziomu ekspresji CD10 w dniu zerowym w stosunku do dnia piętnastego była najbardziej znacząca w grupie standardowego ryzyka (Ryc. 3).

Aby ocenić stopień zmiany poziomu ekspresji CD10 po zastosowaniu prednizonu (podanie przez $8 \mathrm{dni}$ ), pacjenci zostali podzieleni na dwie grupy, pod względem stosunku poziomu ekspresji CD10 wyrażonego jako MFI w dniu zerowym i dniu piętnastym. W grupie pacjentów, u których stosunek ten wynosił mniej niż 1, nie zaobserwowano znaczących różnic w odpowiedzi na prednizon. W przypadku pacjentów, u których stosunek wynosił więcej niż 1, zaobserwowano znacząco lepszą odpowiedź na prednizon (Ryc. 4).

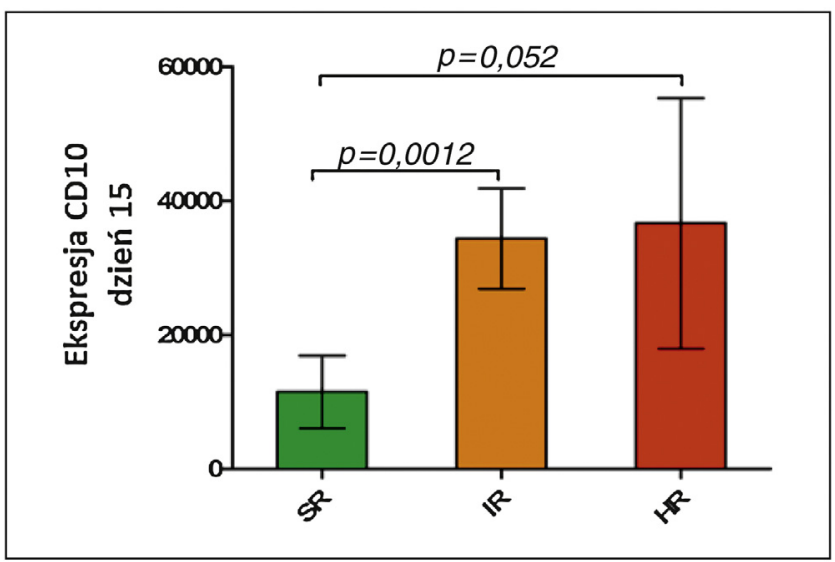

Ryc. 2 - Poziom ekspresji CD10 w dniu piętnastym w zależności od grupy ryzyka: standardowego (SR), pośredniego (IR) i wysokiego (HR)

Fig. 2 - The level of CD10 expression at day 15 in standard risk (SR), intermediate (IR) risk, and high-risk (HR) groups

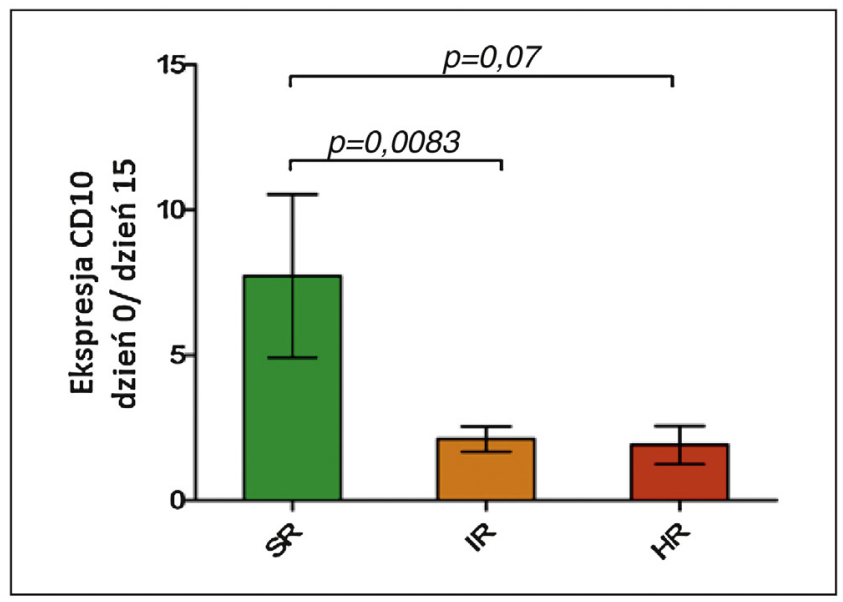

Ryc. 3 - Stosunek ekspresji CD10 w dniu zerowym i dniu piętnastym w zależności od grupy ryzyka: standardowego (SR), pośredniego (IR) i wysokiego (HR)

Fig. 3 - Ratio of CD10 expression at day 0 and 15 in standard risk (SR), intermediate (IR) risk, and high-risk (HR) groups

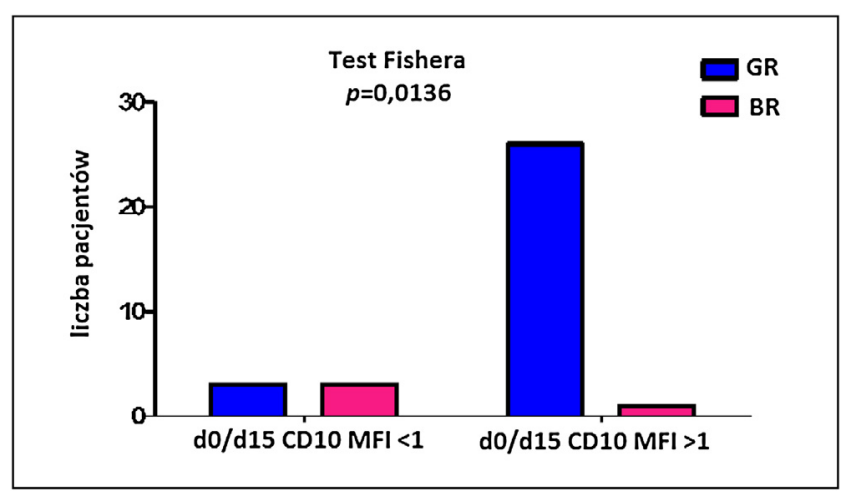

Ryc. 4 - Rozróżnienie pacjentów na dwie grupy: dobrze (GR; good response) i źle (BR; bad response) odpowiadających na zastosowane leczenie prednizonem $\mathrm{z}$ uwzględnieniem stosunku ekspresji CD10 w dniu 0 i 15

Fig. 4 - Two groups: GR - good response to prednisone and BR bad response to prednisone (with ratio of CD10 expression between day 0 and 15)

W trakcie leczenia najczęściej obserwuje się spadek poziomu ekspresji CD10 (Ryc. 5.1). W niektórych przypadkach poziom ekspresji pozostaje niezmienny (Ryc. 5.2) lub wzrasta w stosunku do dnia zerowego (Ryc. 5.3). Występuje istotna statystycznie korelacja (Ryc. 6) pomiędzy poziomem MRD w dniu 15 oraz poziomem ekspresji CD10 wyrażonym jako MFI. Dalsza analiza wskazuje jednak, iż zależność ta zachodzi w największym stopniu w grupie wysokiego ryzyka (Ryc. 7).

\section{Omówienie}

Analiza przedstawionych wyników wskazała, że w dniu diagnozy nie występowały istotne różnice $\mathrm{w}$ poziomie 

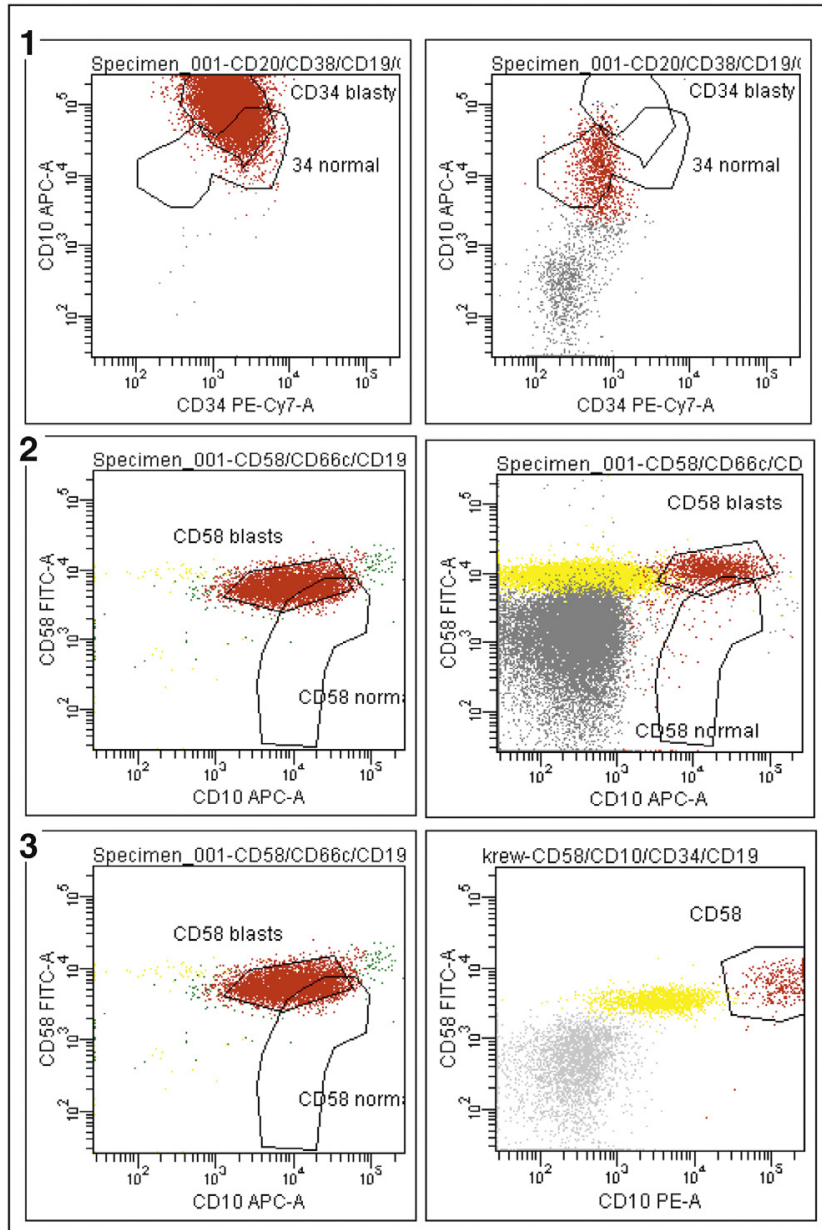

Ryc. 5 - Przykładowy schemat przesunięć w poziomie ekspresji CD10 w czasie leczenia

Fig. 5 - Exemplary scheme of expression shifts of CD10 during treatment

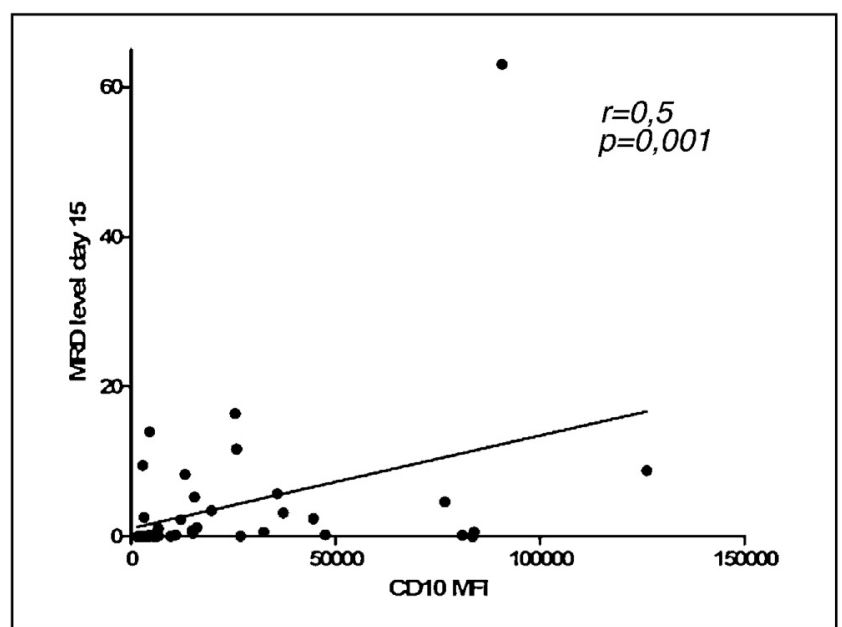

Ryc. 6 - Korelacja poziomu MRD (minimal residual disease) w dniu 15. oraz poziomu ekspresji CD10

Fig. 6 - Correlation of MRD (minimal residual disease) level at day 15 and $\mathrm{CD} 10$ expression level

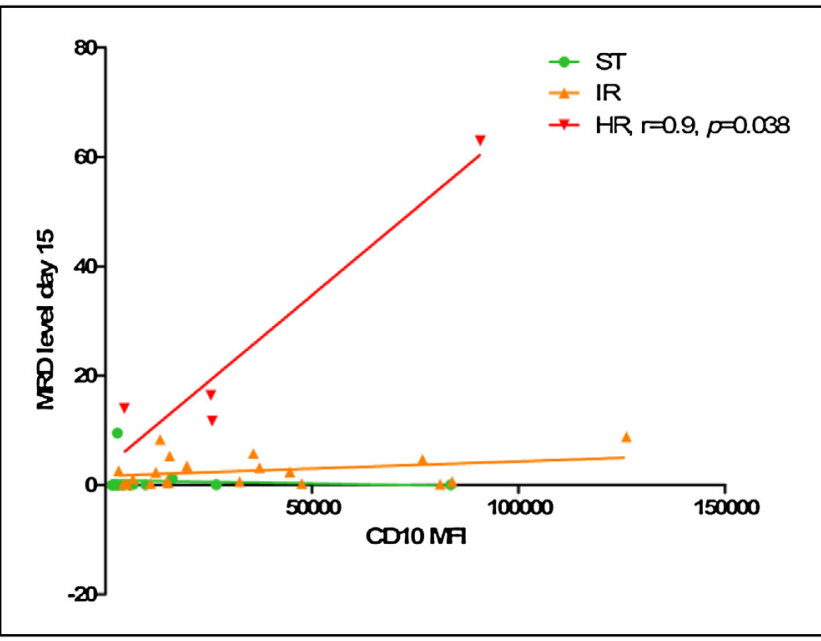

Ryc. 7 - Korelacja poziomu MRD (minimal residual disease) w dniu 15. oraz poziomu ekspresji CD10 w zależności od grupy ryzyka

Fig. 7 - Correlation of MRD (minimal residual disease) level at day 15 and CD10 expression level depends on risk group

ekspresji CD10, wyrażonej jako MFI pomiędzy grupami ryzyka: niskiego, pośredniego i wysokiego. W dniu 15. leczenia w grupie standardowego i pośredniego ryzyka obserwowano spadek poziomu ekspresji, co jest związane $\mathrm{z}$ odpowiedzią na zastosowane leczenie, natomiast $\mathrm{w}$ grupie wysokiego ryzyka nie obserwowano zmian w poziomie ekspresji CD10, a w niektórych przypadkach, wręcz przeciwnie, obserwowano wzrost ekspresji. Poziom CD10 korelował z poziomem blastów w szpiku kostnym w dniu 15. leczenia Zależność ta była najbardziej znacząca u pacjentów należących do grupy wysokiego ryzyka. U pacjentów, u których poziom ekspresji CD10 wzrósł w czasie terapii (stosunek CD10 wyrażonego jako MFI pomiędzy dniem 0 a 15 niższy od 1), był znacząco statystycznie powiązany ze złą odpowiedzią na zastosowane leczenie $\mathrm{z}$ użyciem prednizonu.

\section{Wnioski}

W trakcie leczenia u większości pacjentów obserwuje się zmiany w immunofenotypie komórek białaczkowych. Te modyfikacje często widoczne są już w czasie badań kontrolnych w dniu 15. leczenia. Modulacje w ekspresji CD10 znacząco korelowały z poziomem MRD w dniu 15. Szczególnie było to zauważalne $\mathrm{w}$ grupie wysokiego ryzyka. Brak zmian $\mathrm{w}$ poziomie ekspresji CD10 był związany $\mathrm{z}$ gorszą odpowiedzią na leczenie $\mathrm{z}$ zastosowaniem prednizonu (w dniu 8.). Podsumowując, nie tylko ilościowy wynik MRD, ale także jakościowe zmiany w immunofenotypie komórek białaczkowych mogą przynosić dodatkowe klinicznie istotne informacje.

\section{Wkład autorów/Authors' contributions}

Według kolejności. 


\section{Konflikt interesu/Conflict of interest}

Nie występuje.

\section{Finansowanie/Financial support}

Nie występuje.

\section{Etyka/Ethics}

Treści przedstawione $\mathrm{w}$ artykule są zgodne $\mathrm{z}$ zasadami Deklaracji Helsińskiej, dyrektywami EU oraz ujednoliconymi wymaganiami dla czasopism biomedycznych.

\section{P IŚ M I E N N I T W O/REFERENCES}

[1] Pui C, Robison LL, Look AT. Acute lymphoblastic leukaemia. Lancet 2008;371:1030-1043.

[2] Rana ZA, Rabbani MW, Sheikh MA. Outcome of childhood acute lymphoblastic leukaemia after induction therapy-3 years experience at a single paediatric oncology centre. J Ayub Med Coll Abbottabad 2009;21(4):150-153.

[3] Fader S, Kantarjian HM, Talpaz M. Clinical Significance of Cytogenetic Abnormalities in Adult Acute Lymphoblastic Leukemia. Blood 1998;91(11):3995-4019.

[4] Randolph TR. Advances in acute lymphoblastic leukemia. Clin Lab Sci 2004;17(4):235-245.

[5] Włodek J, Najder K, Bukowska-Strakova K. Rola oksygenazy hemowej 1 w odpowiedzi na G-CSF, podawany u dzieci z ostrą białaczką limfoblastyczną, z powodu neutropenii indukowanej chemioterapią. Acta Mygenica 2015;8:74-83.

[6] Locatelli F, Schrappe M. How I treat relapsed childhood acute lymphoblastic leukemia. Blood 2012;120:2807-2816.
[7] Paietta E. Assessing minimal residual disease (MRD) in leukemia: a changing definition and concept? Bone Marrow Transplantation 2002;29:459-465.

[8] Campana D. Minimal Residual Disease in Acute Lymphoblastic Leukemia. ASH Education Book December 4, 2010;1:7-12.

[9] Antoni Dyduch (red.): Pediatria. T. 2. Katowice: ŚUM, 2009, s. 79-80.

[10] Borowitz MJ, Wood BL. Prognostic significance of minimal residual disease in high risk B-ALL: a report from Children's Oncology Group study AALL0232. Blood 2015;126:964-971.

[11] Rowan RM, Bain BJ. Immunophenotyping in the diagnosis of acute leukaemias. General Haematology Task Force of BCSH. J Clin Pathol 1994;47(9):777-781.

[12] Balan-Nowak A, Zdziłkowska E. Cytometria przepływowa w diagnostyce immunofenotypowej ostrych białaczek. Postępy biologii komórki 2008;35(24):65-102.

[13] Chiaretti S, Zini G. Diagnosis and Subclassification of Acute Lymphoblastic Leukemia. Mediterranean Journal of Hematology And Infectious Diseases 2014;6(1):1-14.

[14] Jagoda K, Stella-Hołowiecka B. Badanie choroby resztkowej (MRD) metodą cytometrii przepływowej w ostrej białaczce limfoblastycznej z linii T (T-OBL) u dorosłych. Acta Haematologica Polonica 2004;4:457-467.

[15] Inaba H. Glucocorticoid use in acute lymphoblastic leukemia: comparison of prednisone and dexamethasone. Lancet Oncol 2010;11(11):1096-1106.

[16] Gaipa G, Basso G. Prednisone induces immunophenotypic modulation of CD10 and CD34 in nonapoptotic B-cell precursor acute lymphoblastic leukemia cells 2008;74 (3):150-155.

[17] Hiroto Inaba, Ching-Hon Pui. Glucocorticoid use in acute lymphoblastic leukemia: comparison of prednisone and dexamethasone. Lancet Oncol 2010 November;11(11):10961106.

[18] Gaipa G, Basso G, Aliprandi S, Dworzak M. Prednisone Induces Immunophenotypic Modulation of CD10 and CD34 in Nonapoptotic B-Cell Precursor Acute Lymphoblastic Leukemia Cells. Cytometry Part B (Clinical Cytometry) 2008;74B:150-155.

[19] Gołąb J. Immunologia. Warszawa: Wydawnictwo Naukowe PWN; 2009: 88. 